\title{
Implementation of the Employment Social Security Administering Body's Responsibilities for Workers Who Have Accidents
}

\author{
Ratna Indayatun ${ }^{1}$, Riswadi $^{2}$ \\ \{ratna.indayatun@gmail.com ${ }^{1}$, riswadi@borobudur.ac.id ${ }^{2}$ \} \\ Universitas Borobudur, Jakarta, Indonesia ${ }^{1,2}$
}

\begin{abstract}
This study aims to describe how the Work Accident Insurance program at BPJS Ketenagakerjaan protects workers who have work-related accidents and looks at how BPJS Ketenagakerjaan provides the form of protection protects workers who have work-related accidents. To collect data, this research utilizes an empirical legal approach combined with a literature review. The findings of this study show that the Employment Social Security Administering Body's Responsibilities to Workers Who Have Workplace Accidents are being implemented.
\end{abstract}

Keywords: Responsibility; Work Accident; Labor

\section{Introduction}

A just and prosperous society will be achieved if the state provides opportunities for physical development, among others, in the form of growth in the industrial sector, while nonphysical in the form of mental and spiritual development of the community [1]. Implementing such action will require a lot of human resources in qualified workers who master science and technology [2]. In Indonesia, a Limited Liability Company that can provide opportunities for the community to get a job and indeed already has a lot of workers, the company in carrying out its production activities will not be able to produce a product without workers. There are three types of workers, namely, contract workers, permanent workers, and part-time workers [3]. In addition to producing production, workers cannot be ignored in their existence in a company. In addition to providing a product that can benefit the company, they also act as skilled workers in their fields. So that the production process tends to use material equipment, and uncontrolled work methods can result in damage, loss, and even fatalities [4]. By working in a company, the relationship between workers and employers arises.

The problem of labour relations is the relationship between workers and employers in which there are rights and obligations reciprocally. One of the obligations of the entrepreneur is to provide guarantees for the protection of workers. The government has made various efforts: the labour social security program, often known as BPJS Ketenagakerjaan. The work accident insurance program means that workers are affected by work accidents caused by accidents or work negligence. Many accidents occur to workers. For example, the company immediately reports to PT for factory workers who often experience accidents related to 
production machines. BPJS Ketenagakerjaan, if the worker has an accident at work and takes care of all procedures, the requirements needed to guarantee the cost of the worker's work accident. Work Accident Insurance consists of the cost of transporting workers who have a work accident, medical treatment costs, rehabilitation costs, compensation for temporary wages unable to work (STMB), partial permanent disability compensation, permanent total disability compensation, death compensation, funeral expenses, Periodic compensation for those who die and are permanently disabled.

\section{Methodology}

The type of research carried out in this research is normative-empirical legal research [5], namely legal research regarding the enforcement or implementation of normative legal provisions (codification, laws, or contracts) in action on every particular legal event in society. The permitted event in question is the Implementation of BPJS Employment Responsibilities for Workers Who Have Work Accidents [6]. The approach used in writing this paper is a juridical-empirical approach that uses secondary data and primary data derived from books, or legal literature, legislation, interviews and other materials. The use of this normative-empirical approach is a combination of a normative legal process with various empirical elements [7].

In getting the correct data in discussing this paper and following the problem approach used in this study, the types of data used in this study are divided into two, namely: Primary Data, namely data obtained directly from the field through interviews from the BPJS Ketenagakerjaan office in Tegal Regency and Secondary data is data received or collected utilizing literature/library study by collecting data such as legislation, jurisprudence, and other literature books.

\section{Results and Discussion}

\subsection{Implementation of the Work Accident Insurance Program at BPJS Ketenagakerjaan for Workers Who Experience Work Accidents}

Work Accident Insurance is a program from BPJS Employment to protect workers in a company against the risk of accidents for participants who have registered with BPJS Employment.[8] In the JKK program, participants must pay a fee to be paid by the company where they work based on the law. BPJS Employment participants who have an accident while working must get special compensation for participants who die from an accident caused by the worker while working. The heirs are entitled to compensation from BPJS for 48 times the work; the family can report it to the social security administering agency employment.

A work accident is a disaster that occurs in a working relationship, both an accident at work and an accident on the way from home to work or vice versa. Everything related to illness is caused by the work environment when doing their job. According to Ministerial Regulation No. 3 of 1994 concerning the Employment Social Security program, the definition of work accidents is accidents related to work relations, including diseases that arise due to work relationships as well as accidents that occur on the way from home to work and returning home through normal or normal roads. Humans in living life always face 
uncertainty, speculative uncertainty and pure uncertainty that will cause harm to themselves and others [9].

All workers are entitled to the BPJS Employment program, but considering that the ability of the community, in general, is different and companies in financing are not necessarily able to, then based on Law no. 24 of 2011 concerning the Employment Social Security Administering Body, article 15 paragraph (1), which states that the employer must gradually register himself. His work as a participant with the BPJS under the social security program being followed. participants described in Law No. 13 of 2003 concerning Manpower Article 10 explains about welfare facilities for workers which reads:

Paragraph (1) "To improve the welfare of workers or labourers and their families, employers are obliged to provide welfare facilities". Paragraph (2) "Provision of welfare facilities as referred to in paragraph (1) is carried out by taking into account the needs of workers/labourers and the size of the company's capabilities".

Work accidents are a type of work risk that can happen wherever they are. In any field of work, the consequences of work accidents can be of various kinds, ranging from minor injuries, severe injuries, partial disability, functional disability, total disability and even death. To provide a sense of security when doing work, the employer must protect the transfer of work risks to BPJS Ketenagakerjaan.

In the implementation of the work accident insurance program organized by BPJS Ketenagakerjaan, as stated in Article 9 paragraph (2) of Law Number 24 of 2011 concerning the Employment Social Security Administering Agency, it is noted that: "BPJS Ketenagakerjaan as referred to in Article 5 paragraph (2) letter $b$ has the function of organizing a pension insurance program, old-age insurance".

There are two types of work accidents, the leading causes of which are:

a. Technical Cause, technical causes are types of accidents that usually involve work environment problems caused by work tools. This equipment is not following work standards for workers to do their work in the field, and the work environment is quite extreme.

b. Cause Human, because humans are usually caused by someone's negligence when doing their work, which often occurs due to individual deficiencies such as not being careful when working, being careless when using work tools, not carrying out their duties properly, and being sleepy when working so on.

Work Accident Insurance is a guarantee that provides compensation and rehabilitation for workers who experience work accidents, both when starting from home to work until arriving back home or suffering from work-related illnesses, according to PP No. 44 of 2015 concerning the Implementation of Work Accident Insurance and death insurance, namely:

a. Health services at designated health facilities following their medical needs are carried out by health facilities provided by the government, local government, or private sector that meet the requirements and cooperate with BPJS Ketenagakerjaan following the provisions of the legislation.

b. Cash compensation includes, the reimbursement of transportation costs for participants who have an accident at work or illness caused by their work environment and when workers travel to or from work, including the cost of first aid in an accident, includes:

1. If using land, river, or lake transportation, a maximum of IDR 1,000,000.00 (one million rupiahs).

2. If using sea transportation, a maximum of Rp. 1,500,000.00 (one million five hundred thousand rupiahs). 
3. If using air transportation, a maximum of Rp. 2,500,000.00 (two million five hundred thousand rupiahs).

4. If using more than 1 (one) transportation, they are entitled to the maximum cost of each vehicle used.

c. Funeral Fee: IDR 3,000,000.00,-

The financing mechanism is to prevent the loss of part or all of the income caused by death or disability due to an accident at the time of work, both physically and mentally. It is necessary to have work accident insurance. Workers who experience work accidents while doing their work are entitled to work accident insurance in the form of reimbursement of costs including:

1. The cost of transporting workers who have an accident at work to the hospital or their home, including the cost of first aid at the time of the accident.

2. Treatment, examination fees, hospitalization, including outpatient care and medicines.

3. Rehabilitation costs in the form of aids (orthoses) and or replacement equipment (protheses) for workers who have an accident and result in missing or non-functioning limbs.

4. Compensation in the form of money includes:

a. The temporary reward for being unable to work

b. Partial compensation forever

c. Total disability compensation forever, both physically and mentally

d. Death benefit

Employers are obligated to report when a worker has an accident while working to the office of the Ministry of Manpower and the Organizing Agency within no more than 2 x 24 hours after the worker who is in an accident by the doctor who treats him is declared to have recovered, is disabled or passed away. The entrepreneur is obliged to take care of the rights of workers who are affected by accidents while working to the Social Security Administering Body until they obtain their rights.

Furthermore, after discussing compensation and costs for workers who have accidents while working, there are also categories of employers (companies) other than state officials according to Government Regulation No. Persons, Apart from Providers, Employers, Workers, and Recipients of Contribution Assistance in the Implementation of Social Security Article 1 paragraph 5". There are various types of employment, namely:

a. A person, partnership, or legal entity that runs a company of its own.

b. Individuals, partnerships, or legal entities that independently run a company that is not theirs.

c. A person, partnership or legal entity was residing in Indonesia, representing the company as referred to in letters a and b, which is domiciled outside the territory of the Indonesian state.

There are various efforts to provide labour protection, one of which is the social security of workers as contained in the Outline of State Policy (GBHN) which reads as follows: "labour protection which includes the rights of association and collective bargaining, occupational safety and health, social security human resources which have old-age insurance, health care insurance, accident insurance and death insurance. The benefits of the Occupational Accident Insurance (JKK) are health services in accordance with medical needs, including primary and supporting examinations, first and advanced level care, Class I (one) hospitalization, government hospitals, regional government, or hospitals. A private hospital is equivalent to intensive care, diagnostic support, treatment, special services, medical devices and implants, doctor or medical services, surgery, medical rehabilitation and blood transfusion. 
3.2 The form of protection from the Employment Social Security Administering Body in protecting workers who experience accidents while working

\section{a) Provision of Health Services}

According to the Indonesian Ministry of Health, the provision of health is an effort to organize individually or together in organizations to prevent and improve health, maintain and cure disease, and restore the health of individuals, groups, families, and or the public [10].

Health services have a purpose in running the system, among others, namely:

1. Promoting or maintaining and improving health is very much needed as in improving nutrition.

2. Preventive, or Prevention of people who have a risk of disease which consists of:

a. Primary Prevention: is composed of educational programs such as immunization, provision of good nutrition.

b. Secondary Prevention: is the treatment of early-stage disease.

c. Tertiary Prevention: is disease diagnosis, diagnosis and treatment.

3. Curative is the healing of a disease.

4. Rehabilitation is the process of restoring and treating.

The types of Health Services obtained include:

1. Medical Services, health services in which a group of medical services (medical services) are characterized utilizing organizing which can be solo (solo practice) or jointly in an organization. The most important goal is to cure disease and restore health, and the main goal is for individuals and families.

2. Public Health Services, the existing health services in the public health service are characterized by way of organizing which is generally carried out together in an organization. The most important goal is to maintain and promote health and prevent disease. At the same time, the targets are groups and communities.

\section{b) Compensation}

Based on the SJSN Law, which includes getting compensation, namely when workers have an accident from home to work or vice versa, and illness caused by the work environment. Participants who experience work accidents or work-related illnesses are entitled to JKK benefits, which are compensation for partial anatomical disability, partial functional disability, and permanent total disability. What is meant by "partial anatomical disability", "partial functional disability", and "permanent total disability" are as follows:

1. Partial Anatomical Defect, it is a state of reduced or lost part of the body which directly or indirectly results in the reduction or loss of the worker's ability to carry out his work.

2. Partial Functional Disability, it is a state of reduced or partial loss of limb function, which directly or indirectly results in reduced or failure of the worker's ability to carry out his work.

3. Permanent Total Disability, it is a disability that results in a person's inability to do work. The condition where one right thumb segment is missing is part of the anatomical defect. For partial disability, workers are entitled to disability compensation. Disability compensation for partial anatomical defects is \% according to the table $\mathrm{x} 80 \mathrm{x}$ monthly wages. The table on the percentage of compensation given can be seen in Roman II, Annex III of PP 44/2015. 
Based on the table of compensation percentages, if the worker loses the thumb of his right hand, then the ratio is $15 \%$ of his wages.

\section{c) Back to Work Program}

The government has issued Permenaker No. 10 of 2016 concerning procedures for providing a return to work program and promotive and preventive activities for work accidents and occupational diseases. The Permenaker has been in effect since March 10, 2016. The Minister of Manpower, M Hanif Dhakiri, said that the return to work program, also known as the return-to-work program, is aimed at workers who experience work accidents and workrelated illnesses.

According to Hanif, with the program, it is hoped that workers who experience work accidents or work-related illnesses can return to work after undergoing the rehabilitation process through social protection organized by BPJS Ketenagakerjaan. He said that all workers registered in the BPJS Employment Accident Insurance (JKK) program could get a stuntwork program. Although it is shown that workers who have work accidents can work again, Hanif admits that the Permenaker return to work does not explicitly regulate whether the workers concerned can work in the same job. Or not. According to him, workers can return to work doing the same position and do other jobs adjusted to the conditions after experiencing a work accident. BPJS Ketenagakerjaan can take action to ensure that workers who have participated in the return-to-work program can return to work in the following ways:

1. They enforce the law related to Article 153 paragraph 1 (j) of the Manpower Law and similar provisions in the Law on Persons with Disabilities.

2. The Employer of Return to Work should regulate the role of the Government and BPJS Employment to provide capital support for workers who have disabilities and cannot be accepted in the company.

3. BPJS Employment can place workers after undergoing the return-to-work program to work in various companies whose shares are owned by BPJS Ketenagakerjaan.

BPJS Ketenagakerjaan has made efforts to guarantee and protect workers who experience work accidents with money as a form of compensation in the form of cash as a partial replacement and lost income or reduced services as a result of the work accident. The Manpower Social Security Program is organized to protect the workforce, which can be carried out through an insurance mechanism. Every worker is entitled to Labor Social Security. The government has made efforts to realize the Employment Social Security Administration Program and Agency (BPJS). Every company must carry out workers who carry out work in an employment relationship following the provisions. The Employment Social Security Administering Body Program scope includes Work Accident Insurance, Death Insurance, Old Age Security, and Health Care Insurance.

BPJS Ketenagakerjaan has made efforts for workers who experience work accidents because of the Work Accident Insurance (JKK) program, which is an essential aspect for workers because it involves the implementation of work. Because when in the workplace, all risks must be borne by BPJS Ketenagakerjaan who suffered a work accident, which includes workers in the Work Accident Insurance, namely:

1. Interns and students who work for companies whether they receive wages or not.

2. Those who buy up the work unless it is the company itself.

3. Prisoners employed in the company. 
The work accident insurance may also include:

1. Freight costs.

2. Cost of examination, treatment, and care.

3. Rehabilitation costs.

Costs are borne by BPJS Ketenagakerjaan, such as transportation costs by ambulance, doctor's examination fees, rehabilitation costs such as compensation in the form of money, which includes: (1) The temporary reward for being unable to work. (2) Compensation for partial disability permanently, both physically and mentally. (3)Death benefits.

The process carried out by the company to be able to claim compensation from BPJS Employment must go through several stages. More precisely, there are three primary stages that companies need to understand in claiming Work Accident Insurance. The following are the steps taken to claim compensation: After an employee has a work accident, the news must be received by the company immediately. Thus, the company can immediately fill out the BPJS form, the first stage report of the claim process and BPJS Employment Accident Insurance benefits.

1. The applicable provisions for conducting this phase one work accident report are that the letter is sent no later than $2 \times 24$ hours after the accident. Another requirement is, if a work accident occurs while the employee is on a trip, it must happen on the route usually taken by the employee. Later the equipment requirements must also be included are detailed proof of attendance or presence related to the employee concerned.

2. After the employee has finished being treated by the designated health facility or died in other cases, the company must carry out the second stage. The second stage is to fill out the BPJS form, and this second stage form is sent no later than $2 \times 24$ hours after the employee is asked to recover or die. Furthermore, this submitted form will become the basis used by BPJS Employment to calculate and pay compensation or compensation for work accidents experienced by employees. If the employee recovers, a calculation will be made to pay for the treatment costs. If an employee dies, the analysis is carried out to provide compensation to the heirs of the employee concerned.

3. The submission of the form in the second stage serves as a request for payment for the Work Accident Insurance experienced by the employee. The offeror delivery must be accompanied by a copy of the guarantee participant card or BPJS membership card, a certificate from a doctor who treats the employee, a receipt for medical expenses and a transportation receipt. In practice, this document is usually handled by the hospital. However, to better understand the procedures used, of course, you must know what steps must be taken.

Employers are required to report work accidents that have occurred to their workers to the head of the local Manpower Office and the Employment Social Security Administration within no more than $2 \times 24$ hours. After the worker struck by a work accident is treated, the doctor will declare that the worker is cured, disabled or killed. Employers are required to take care of workers affected by work accidents at BPJS until they obtain their rights. Contributions on work accident insurance, death insurance contributions and health care insurance contributions are all borne by the company. Employers are obligated to pay contributions and collect subsidies that are the workforce's obligation through deductions from workers' wages and deliver them to the Employment Social Security Administering Body within the stipulated time. The calculation of the amount of work accident insurance that must be paid to workers is carried out by the Employment Social Security Administering Agency under established regulations. 
Every worker has the right to develop expertise and honesty to acquire and add work skills and skills so that their potential and creative power can be set to enhance intelligence and work toughness. The government also issues labour/industrial labour regulations regarding work competency standards. Accidents in doing a job are sometimes unavoidable. Work accidents sometimes occur because of the company's attitude that does not care at all about the safety of workers and does not take maximum precautions such as not paying attention to and maintaining machines or not conducting counselling about the production process. Sometimes it also occurs because of fatigue or the way the worker works. Or it could be due to unsafe working conditions and environment so that work accidents are prone to happen to every worker. The program provided by BPJS Ketenagakerjaan is essentially a form of guarantee for employees to be able to work optimally and feel comfortable. Employees get apparent certainty regarding every work risk and various other warranties by participating in the existing program. To complete the requirements for submitting work accident insurance, the company must include proof of absence or presence. This proof can be obtained when the company uses an integrated, valid and complete attendance system.

\section{Conclusion}

The Employment Social Security Program is implemented for workers who experience work accidents based on Law no. 24 of 2011 concerning the Social Security Administering Body. Implementation of labour protection guarantees in a company, especially for Work Accident Insurance (JKK), if there are workers who experience work accidents, the first thing will get treatment from a doctor or the nearest hospital then the costs are claimed BPJS Ketenagakerjaan. This claim covers all medical expenses from start to finish. The guarantee provided is in medical expenses, temporary compensation for not working and transportation costs following Article 29 paragraph (2) of Law Number 40 of 2004 concerning the National Social Security System (UU SJSN).

The form of protection from BPJS Ketenagakerjaan in protecting workers who have accidents at work is in the form of BPJS Employment's responsibilities within working hours as evidenced by the time the accident occurred, namely during working hours, so that it is referred to as a work accident, an accident outside working hours, as evidenced by the time and place of the accident, namely when leaving and coming home from work and the location of the accident must be on the road that will be passed between the house and the place where the worker works or vice versa.

\section{References}

[1] M. I. T. Karim, A. P. Moenta, and M. Riza, "Implementasi Kebijakan Pemerintah Daerah di Bidang Kesehatan Masyarakat Melalui Jaminan Kesehatan Nasional," Amanna gappa, vol. 26, no. 1, pp. 53-63, 2018.

[2] R. Dewi and E. Israhadi, "Legal Aspects of BPJS as National Health Insurance," 2021, doi: 10.4108/eai.6-3-2021.2306412.

[3] A. Kahfi, "Perlindungan Hukum Terhadap Tenaga Kerja," J. Jurisprud., vol. 3, no. 2, pp. 59-72, 2016.

[4] L. C. Wardhani, "Perlindungan Hukum Terhadap Tenaga Kerja Outsourcing Sebelum dan Sesudah Putusan Mahkamah Konstitusi Nomor 100/PUU-X/2002,” 2014. 
[5] S. H. Achmad Ali and S. H. Wiwie Haryani, Sosiologi hukum: kajian empiris terhadap pengadilan. Kencana, 2014.

[6] M. Marzuki, Penelitian Hukum: Edisi Revisi. Prenada Media, 2017.

[7] C. Maguire, "Library research: Luxury or necessity?," Aust. Libr. J., vol. 60, no. 4, pp. 298-303, 2011, doi: 10.1080/00049670.2011.10722646.

[8] T. Sudrajat, S. Kunarti, and A. A. Nasihuddin, "Perlindungan Hukum dan Pemenuhan Hak Pekerja pada Program Jaminan Kesehatan Nasional," Pandecta Res. Law J., vol. 15, no. 1, pp. 83-92, 2020, doi: 10.15294/pandecta.v15i1.23647.

[9] D. W. Kim, H. Y. Zhang, J. hyoung Yoo, Y. S. Park, H. J. Song, and K. H. Yang, “The correlation between tympanic membrane temperature and specific region of face temperature," Quant. Infrared Thermogr. J., vol. 16, no. 1, pp. 1-7, 2019, doi: 10.1080/17686733.2018.1497877.

[10] Syaharuddin et al., "ANN Back Propagation in forecasting and policy analysis on family planning programs: A case study in NTB Province," J. Phys. Conf. Ser. SEASTEM 2020, vol. 1, no. 1, pp. 1-7, 2020, doi: 10.1088/1742-6596/1882/1/012036. 